\title{
Images of Anesthesia
}

Michael G. D'Souza MD, Admir Hadzic MD PhD, T. Wider MD
Unilateral mydriasis after nasal reconstruction surgery

Purpose: To present a case of iatrogenic, unilateral pupillary dilatation after general anesthesia for nasal surgery. Unilateral pupillary dilatation after general anesthesia has sinister implications, which might prompt further investigations. However, in patients undergoing nasal surgery, it might be caused by the action of drugs injected intranasally. Consideration of iatrogenic causes of pupillary dilatation might help clinicians to avoid time-consuming and costly investigations.

Clinical features: A 24-yr-old healthy woman underwent a general anesthetic for septoplasty and bilateral turbinectomy. She was hemodynamically stable and did not suffer any hypoxia intraoperatively. At the end of the operation her right pupil was dilated (8 $\mathrm{mm}$ diameter). Her left pupil was normal. No other abnormality was detected. After she woke up, her vision was grossly normal. Neurological examination did not show any other abnormality. Six to eight hours later, both pupils were equal ( $2 \mathrm{~mm}$ in diameter) and reacting normally to light and accommodation.

Conclusion: The patient was a healthy 24-yr-old who underwent an operation in which there was no incident of hypoxia or hemodynamic instability. Since the patient recovered completely within six to eight hours, the pupillary dilatation was probably caused by epinephrine, which could have entered the eye through the nasolacrimal duct. Although pupillary dilatation after general anesthesia has been described, this is the first case report where the most likely causative agent was epinephrine, injected into the nasal submucosa.

Objectif : Présenter un cas de dilatation pupillaire iatrogénique unilatérale survenue après l'anesthésie générale pour une intervention chirurgicale nasale. Cette situation présente de graves implications qui peuvent demander des investigations supplémentaires. Dans les cas d'une intervention nasale, la dilatation peut être causée par l'action du médicament injecté dans le nez. Un examen attentif de ses causes iatrogéniques peut éviter des recherches longues et coûteuses.

Éléments cliniques : Une femme de 24 ans en bonne santé a subi une anesthésie générale pour une septoplastie et une turbinectomie bilatérale. L'hémodynamie était stable et la patiente n'a pas souffert d'hypoxie peropératoire. À la fin de l'intervention, sa pupille droite s'est dilatée (8 $\mathrm{mm}$ de diamètre). Sa pupille gauche était normale. Aucune autre anomalie n'a été détectée. Au réveil, la vision était sensiblement normale et l'examen neurologique n'a pas montré d'autre complication. Six à huit heures plus tard, les deux pupilles étaient égales ( $2 \mathrm{~mm}$ de diamètre) et réagissaient normalement à la lumière et à l'accommodation.

Conclusion : Une patiente de 24 ans a subi une opération qui n'a pas présenté d'hypoxie ou d'instabilité hémodynamique. La dilatation pupillaire observée, avant une récupération complète qui a eu lieu de six à huit heures après l'opération, était probablement causée par l'épinéphrine qui a pu pénétrer dans l'œil par le canal nasolacrimal. La dilatation pupillaire qui suit une anesthésie générale a déjà été décrite, mais c'est la première fois qu'on observe un cas où elle serait causée par l'épinéphrine injectée dans la sous-muqueuse nasale.

From the Department of Anesthesiology, St. Luke's/Roosevelt Hospital Center, 1111 Amsterdam Avenue, Travers 7, Rm701, New York, NY 10025, USA.

Address correspondence to: Michael G. D’Souza MD. Phone: 212-523-2500; Fax: 212-523-3930; E-mail: mgd11@columbia.edu Financial support has not been received from any source.

Accepted for publication June 28, 2000. 
Case Report

We report an unusual occurrence of unilateral mydriasis at the end of a general anesthetic in a patient undergoing nasal septoplasty and turbinectomy. A 24yr-old previously healthy woman was scheduled for septoplasty, bilateral turbinectomy and liposuction of the lower torso and legs. A recent general anesthetic for minor plastic surgery was uneventful. She did not have a history of previous nasal trauma or surgery. The only medication she was taking was oral contraceptives. She was $163 \mathrm{~cm}$ tall and weighed $67 \mathrm{~kg}$. No premedication was given in the ambulatory anesthesia unit. Anesthesia was induced with $2 \mathrm{mg}$ midazolam, $250 \mu \mathrm{g}$ fentanyl, $170 \mathrm{mg}$ propofol and $7 \mathrm{mg}$ vecuronium. Following intubation with a $7.0 \mathrm{~mm}$ cuffed orotracheal tube, anesthesia was maintained with isoflurane, oxygen and nitrous oxide. Her eyes were lubricated with a lubricant ophthalmic ointment (Duratears naturale ${ }^{\circledR}$, Alcon, Fort Worth, TX) and taped. Prior to incision, the surgeon infiltrated the soft tissue envelope of the nose, mucosa of the inferior turbinate and the mucosa of the septal cartilage with $20 \mathrm{ml}$ lidocaine $1 \%$ with 1:200,000 epinephrine. A total of $550 \mu \mathrm{g}$ fentanyl, $17 \mathrm{mg}$ vecuronium, $1000 \mathrm{mg}$ cefazolin, and 35 $\mathrm{mg}$ labetalol and $8 \mathrm{mg}$ hydralazine to maintain the systolic blood pressure between 80 and $100 \mathrm{~mm} \mathrm{Hg}$, were given intraoperatively. The patient received a total of four litres lactated Ringer's solution. Her urine output was $270 \mathrm{ml}$ and blood loss was estimated to be $200 \mathrm{ml}$.

At the end of the 4.5 hour operation, the tape covering the eyes was removed. It was noticed that her right pupil was dilated $(8 \mathrm{~mm})$ and reacting with barely perceptible motion, to light. Her right pupil was 2 $\mathrm{mm}$ in diameter and reacting normally to light. Consensual reaction was present on the left. Neuromuscular paralysis was reversed with $0.5 \mathrm{mg}$ glycopyrrolate and $2.5 \mathrm{mg}$ neostigmine. On examination during neurology consultation two hours after conclusion of anesthesia, she was awake, alert and oriented in time and space. Her right pupil was dilated ( 8 $\mathrm{mm}$ ), round, and reacting minimally to light and accommodation (Figure 1). The left pupil was $2 \mathrm{~mm}$ in diameter and reacting to light and accommodation. The consensual reaction was present and her vision and eye movements appeared to be grossly normal. The rest of routine neurologic examination was unremarkable. The right pupil returned to normal within the next six to eight hours.

Discussion

The most likely cause of pupillary dilatation in our patient was the passage of epinephrine through the

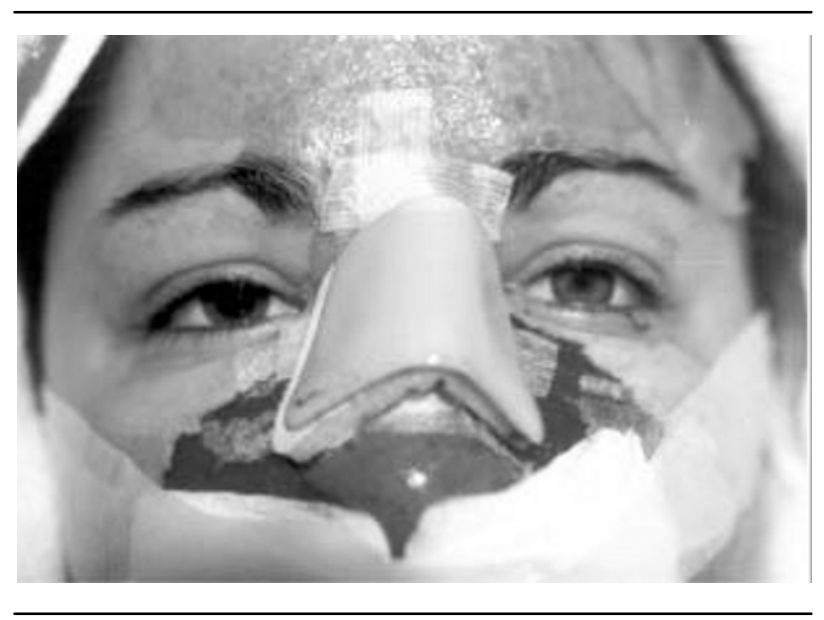

FIGURE 1 The patient about $30 \mathrm{~min}$ after surgery. The left pupil is dilated. The right pupil appears normal.

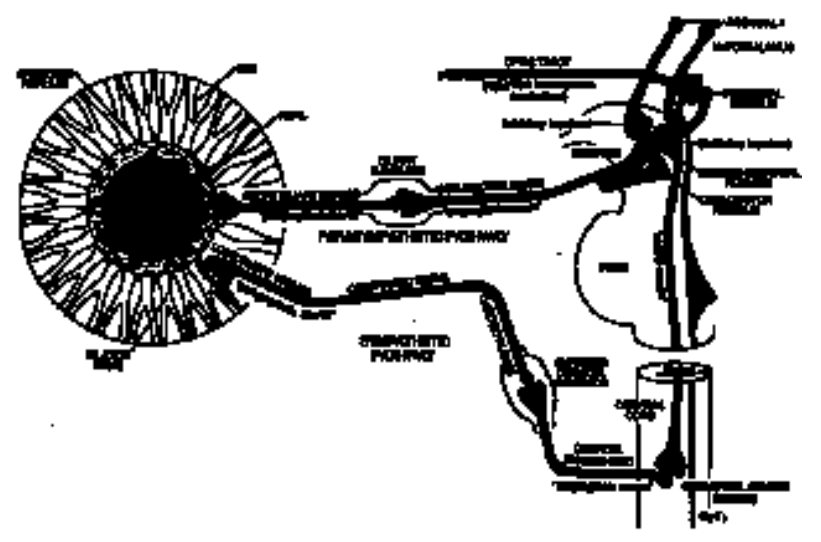

FIGURE 2 Innervation of the iris muscle, showing the pathways and the terminology in general use. Note that an alerting stimulus dilates the pupil in two ways - it inhibits the iris sphincter and a moment later the dilator muscle contracts. (Reproduced from Thompson HS. The Pupil. In: Hart WM (Ed.). Adler's physiology of the Pupil. Mosby Year Book, 1992: 421, with permission).

nasolacrimal duct, into the eye. The size of the pupil depends on the balance between the sympathetic (dilator) and parasympathetic (constrictor) systems. Sympathetic pathways originate in the hypothalamus and enter the upper thoracic spinal cord, synapsing in the interomediolateral cell column of spinal segments $\mathrm{C}_{8}-\mathrm{T}_{2}$. The post ganglionic fibres ascend along the internal carotid artery and follow the ophthalmic division of the trigeminal nerve into the orbit, to innervate the pupillodilator muscle (Figure 2 ). The parasympa- 
thetic fibres regulating pupillary constriction originate in the Edinger-Westphal nucleus, adjacent to the oculomotor nucleus in the midbrain. These fibres travel with the oculomotor nerve to synapse in the ciliary ganglion in the posterior orbit. The postganglionic fibres innervate the sphincter pupillae controlling constriction and innervate the ciliary smooth muscle regulating accommodation (Figure 2).

While the most feared causes of a unilateral, acutely dilated pupil likely to be encountered by anesthesiologists include a cerebrovascular event, a mass lesion and cerebral or globe trauma, more benign causes are also common. Anisocoria $0.4 \mathrm{~mm}$, without ophthalmoplegia is normally present in about $20 \%$ of the general population. ${ }^{1}$ Direct trauma to the globe of the eye, traumatic iridoplegia or rupture of the iris sphincter by the contusion may all lead to an irregular pupil. ${ }^{2}$ A normal level of consciousness and vision excludes the most serious causes of unilateral pupillary dilatation.

Gibson et $a l .^{3}$ reported postoperative unilateral mydriasis after nasal reconstruction surgery where topical cocaine and mucosal injections of lidocaine and epinephrine were used by the surgeons. The authors postulated that the retrograde passage of cocaine was most likely responsible for the mydriasis. Others have reported unilateral mydriasis possibly due to leakage of phenylephrine nose drops (used for mucosal vasoconstriction) through the nasolacrimal duct to the eye. ${ }^{4,5}$ Holmgreen et al. described unilateral mydriasis and paralysis of accommodation in a patient who received local injection of lidocaine and epinephrine for extraction of impacted third molars. ${ }^{6}$ The authors postulated that in this case lidocaine might have traversed the pterygopalatine fossa and the inferior orbital fissure to enter the orbit and anesthetize the ciliary ganglion. Unilateral mydriasis has also been reported after topicalization with lidocaine and phenylephrine with the help of an oxygen driven face mask nebulizer. ${ }^{7}$

Unlike previous reports, topical cocaine or phenylephrine was not used in our patient. This is the only reported case of isolated mydriasis after nasal submucosal injection of lidocaine and epinephrine. Since she did not have any blurring of vision, it is unlikely that her ciliary ganglion was affected. Lidocaine is unlikely to be the cause as instillation of lidocaine into the conjunctival sac does not cause pupillary dilatation. Thus, the pupillary dilatation in our patient was most probably caused by epinephrine, which could have entered the eye through the nasolacrimal duct.

The absence of previous medical history and intraoperative hemodynamic instability in our patient did not raise concern of the possibility of intracranial insult as a cause of the postoperative neurologic deficit. Thus, when assessing perioperative unilateral mydriasis, accidental iatrogenic exposure to mydriatic agents and topical anesthesia before or during surgery should be considered as possible causes before a more aggressive approach to diagnosis and treatment is assumed.

\section{References}

1 Lam BL, Thompson HS, Corbett JJ. The prevalence of simple anisocoria. Am J Opthalmol 1987; 104: 69-73.

2 Klein $O G \mathrm{Jr}$. The initial evaluation in ophthalmic injury. Otolaryngol Clin North Am 1979; 12: 303-20.

3 Gibson BE, Stanley RJ, Lanier WL. Prolonged unilateral mydriasis after nasal septal reconstruction (Letter). Anesth Analg 1987; 66: 197-8.

4 Rubin MM, Sadoff RS, Cozzi GM. Postoperative unilateral mydriasis due to phenylephrine: a case report. J Oral Maxillofac Surg 1990; 48: 621-3.

5 Louis F, Diab M. Prolonged unilateral mydriasis after nasotracheal intubation. Middle East J Anesthesiol 1998; 9: 471.

6 Holmgreen WC, Baddour HM, Tilson HB. Unilateral mydriasis after general anesthesia. J Oral Surg 1979; 37: 740-2.

7 Prielipp RC. Unilateral mydriasis after induction of anaesthesia. Can J Anaesth 1994; 41: 140-3. 